\title{
Minangkabau in Film Integrative Learning Media for Alam Minangkabau
}

\author{
Herry Nur Hidayat ${ }^{1 *}$, Bani Sudardi ${ }^{2}$, Sahid Teguh Widodo ${ }^{3}$, Sri Kusumo Habsari ${ }^{4}$ \\ ${ }^{1}$ Fakultas Ilmu Budaya Universitas Andalas Padang, Indonesia \\ ${ }^{2,3,4}$ Fakultas Ilmu Budaya Universitas Sebelas Maret Surakarta, Indonesia \\ *Corresponding author. Email: herrynh@hum.unand.ac.id
}

\begin{abstract}
Minangkabau culture, traditions, and social structure seem to be unlimited sources of art, especially movies. However, the use of this Minangkabau film is not used maximally. This paper describes Minangkabau-contained film's possibility as the learning media for the subject matter Alam Minangkabau. The density of the continuity content in the film can be used as integrative teaching material. In this case, Minangkabau content is identified, discovered, and explored through storytelling elements that build the film's story. In developing teaching materials, the Minangkabau content in the film is then developed by connecting it to everything related. The results are then sorted, selected, and compiled into teaching materials Alam Minangkabau. The results, various aspects and elements of continuity can be explored, interpreted, and criticized. Besides enriching students 'knowledge about Minangkabau, film as a teaching material can inspire students' critical thinking skills, especially about the Minangkabau culture and traditions.
\end{abstract}

Keywords: Minangkabau, film, media, learning.

\section{INTRODUCTION}

The learning process in the classroom refers to the mass communication process. This process marks the number of actors in the communication act. Mass communication is a process by a person or group conveying messages and transmitting them through a medium to numerous audiences [1]. In this case, the media is an essential factor in the learning process. Media selection and facilitating material delivery can arouse students' interest and enthusiasm in participating in the learning process. Also, both educators and students can sharpen critical and creative thinking skills. The learning process is not merely measured by mastering the material but the implications of the learning material for the students' lives.

On the other hand, the development of technology and information today requires educators' creativity to sort and choose the right learning media for students. Students' mastery of technology and information seems to be a concern for many educators to determine the right learning media. This burden increases for educators with local content material that students consider old, outdated, undeveloped, boring, and unattractive.
The choice of media is essential because the learning process tends to be carried out using the TeacherCentered Learning (TCL) method, which is verbal. Students' creativity and critical thinking will not be maximally explored because students are more likely to memorize teaching material than to understand it. With audio-visual learning media selection, students can further develop their knowledge, be creative and critical.

This paper describes the selection of films as learning media for the local content of Alam Minangkabau. According to Gayatri \& Hidayat [2], one of the reasons for students' lack of interest in natural Minangkabau learning materials is the lack of variety and innovation in this learning process. In the end, students' understanding of the material was also significantly reduced.

It should be stated here that currently, the Budaya Alam Minangkabau (BAM) curriculum has been integrated into the Seni dan Budaya teaching material. The quantity of learning hours, which impacts the quality of mastery of the Minangkabau material, is very lacking. However, that does not mean that the Minangkabau material does not need to be taught in students' learning process, especially at the primary education level. By selecting the right media, not only Alam Minangkabau learning materials can be integrated with other teaching 
subjects, but also Alam Minangkabau teaching materials may contain other teaching materials.

The choice of film as a medium of learning, of course, must consider several things. Besides educators' knowledge about films, media affordability is crucial when choosing films as learning media, namely supporting facilities and infrastructure, such as tools and rooms.

As one of the major tribes in Indonesia, not once or twice Minangkabau is shown in the film. Apart from presenting the nature, tradition and folklore are the subjects that appear in films. According to the author's notes, to date (1926 - 2018), there are more than twenty Indonesian film titles that raise Minangkabau content. This record does not count independent films made by institutions or communities.

On the other hand, there have been many studies of Minangkabau-contented films. Saputranur [3] looks at the representation of female characters in Indonesia's religious films in the old era and the modern era, namely by comparing the film Titian Serambut Dibelah Tujuh with the film Ayat-Ayat Cinta 2. Trisnawati \& Yesicha [4] examined the film Tenggelamnya Kapal van der Wijck and found in this film, the Minangkabau people consider the descendants of Minangkabau women. The mamak (uncle) has a position and role that exceeds the father.

Using Bathes' semiotic theory, Fitri [5] found the content of Islam's characteristics in the film Surau dan Silek. Also, the surau in this film represents the traditional Minangkabau educational culture which is rarely found in everyday life. Meanwhile, the film Surau dan Silek, according to Arief [6], is a fictional film that presents the spirit of surau life as a religious institution and silek (silat) as a cultural institution in Minangkabau. In his thesis and article, Woodrich [7] states that Melati van Agam and Siti Noerbaja are two of the several film titles that are adapted from the novel. Melati van Agam is based on the Parada Harahap novel. At the same time, Siti Noerbaja is called a film adaptation of the last novel in the Indonesian film period during the Dutch colonial period.

Thalib [8] called the film Tenggelamnya Kapal van der Wijck as a love film with multicultural issues. Di Bawah Lindungan Ka'bah by Aisya et al. [9] contains the incompatibility of Minangkabau culture with its reality. The visual appearance that appears in the film, according to the researcher, is not the real Minangkabau culture. In his study of films from the Dutch colonial period until early independence, Anggraini [10] mentioned Harimau Tjampa as one of the most influential films. According to her, Harimau Tjampa contains an expression of nationalism while still carrying traditional values. Arief [11] analyzes the Minangkabau cultural context in the film Titian Serambut Dibelah Tujuh and states that many things are contrary to the life philosophy of the Minangkabau people in the film Titian Serambut Dibelah Tujuh.

Pamusuk Eneste, in his book Novels dan Film [12], mentions the differences between the novel and film Salah Asuhan as a form of ekranization that includes various changes. Meanwhile, in his research, Heider [13] said that Salah Asuhan was a form of criticism of racism and social discrimination during the Dutch colonial period. In responding to the Para Perintis Kemerdekaan based on Hamka's novel Di Bawah Lindungan Ka'bah, Junus [14] said that Asrul Sani treats the novel into films according to his reassessment of the past based on current thinking when he was working on films. Meanwhile, it should be underlined that the Minangkabau film's first criticism was the criticism of the film Melati van Agam. Kwee Tek Hoay [15], [16] wrote his critique in Panorama magazine in the section on Pemandangan Filem, divided into two articles. In his writing, Hoay not only criticizes the story but also criticizes the cinematographic elements.

It can be seen that the studies have not touched pedagogical aspects, both in terms of methods and content contained in the film. These studies are only limited to finding and describing the Minangkabau culture's content, traditions, behavior, and habits of the Minangkabau people.

\section{METHOD}

This research is content analysis. In this case, Minangkabau content is identified, discovered, and explored through storytelling elements that build the film's story. The material for this research is several films that are considered to contain Minangkabau elements, namely Harimau Tjampa (1953), Di Bawah Lindungan Ka'bah (2011), Tenggelamnya Kapal Van Der Wijck (2013), Tabula Rasa (2014), Me vs Mami (2016), Surau dan Silek (2017), and Liam dan Laila (2018). In developing teaching materials, the Minangkabau content in the film is then developed by connecting it to everything related. The results are then sorted, selected, and compiled into teaching materials Alam Minangkabau.

\section{LEARNING ALAM MINANGKABAU TROUGH FILM}

The selection of learning media with film can at least fulfill the learning process's objectives and benefits. Some of the benefits that can be obtained are (i) it can foster student motivation because teaching material will attract their attention more; (ii) the learning material will become clearer so that it can be understood by students and allows for mastery and achievement of teaching objectives; (iii) teaching methods will be more varied, not based solely on verbal communication; and (iv) students 
do more activities during learning activities, not only listening but also observing, demonstrating, doing handson, and acting [17], [18].

It has been stated above that not all Minangkabaucontained films can be used as learning media for Alam Minangkabau subjects. Several titles, show the appearance of prowess in them only as part of an intrinsic element, namely supporting the building of the story setting. However, some films contain complex and integrative progress as learning media.

Before discussing the Minangkabau content in these films as a medium of learning, it is also necessary to convey a learning technique alternative using this film media. These methods and techniques consider that the facilities and infrastructure for using films in the learning process (tools and space) have been fulfilled. The alternative sequence is as follows.

Table 1. Learning method and technique using film [19]

\begin{tabular}{|c|c|}
\hline Stage & Activities \\
\hline 1. Planning & $\begin{array}{l}\text { 1. Create and develop learning objectives. } \\
\text { 2. Mastering the material, namely films that will be used as learning media. } \\
\text { 3. Develop a plan of activities in the learning room. }\end{array}$ \\
\hline 2. $\quad$ Preparing & $\begin{array}{l}\text { 1. Introduce and discuss with students the film that will be used as a } \\
\text { medium. } \\
\text { 2. Discuss a general description of the film. } \\
\text { 3. Explain the purpose of using the film. In this case, it can be linked to the } \\
\text { knowledge that students already have. Can show selected scenes to attract } \\
\text { the attention of students. } \\
\text { 4. Introduce the terminology of film. }\end{array}$ \\
\hline 3. Watching film & Watching film \\
\hline 4. Confirmation & $\begin{array}{l}\text { 1. Confirm the results of students after watching the film. Create discussion } \\
\text { related to learning objectives. } \\
\text { 2. Open discussions between students. } \\
\text { 3. Measure the achievement of students' teaching materials. } \\
\text { 4. Give written assignments to students. For example, reports, responses, } \\
\text { essays, or reports. }\end{array}$ \\
\hline
\end{tabular}

As a learning medium for Alam Minangkabau, the films above can adequately fulfill particular material about Minangkabau. The selection of film content can also consider the level of educational grade.

In general, Minangkabau films are characterized and dominated by the visual image of the gonjong roof, both as part of the rumah gadang and rangkiang. The rumah gadang building is a moral space and a symbol of Minangkabau customs. Although the forms of houses in West Sumatra were always changing, the traditional rumah gadang was conceptualized and crystallized, especially during the forced coffee cultivation system (1847-1908) [20]. Rumah gadang has a unique shape. The roof is tapered in the shape of a buffalo horn. The shape of the buffalo horn is often associated with the Minangkabau victory's folklore during the Javanese invasion of Sumatra [21], [22].

In film, rumah gadang appears as the setting of the place, namely the character's residence and part of the place setting's design. Rumah gadang, shown in the film, indirectly shows the owner's social status, namely the ethnic group and not personal. For the Minangkabau community, rumah gadang is not merely a family residence. Rumah gadang is a symbol of one person's presence in one village and the center of life and harmony, such as a place for consensus among the families of the people and carrying out ceremonies [23] [25]. Films that feature quite many visualizations of the rumah gadang are Harimau Tjampa, Di Bawah Lindungan Ka'bah, and Tenggelamnya Kapal van der Wijck.

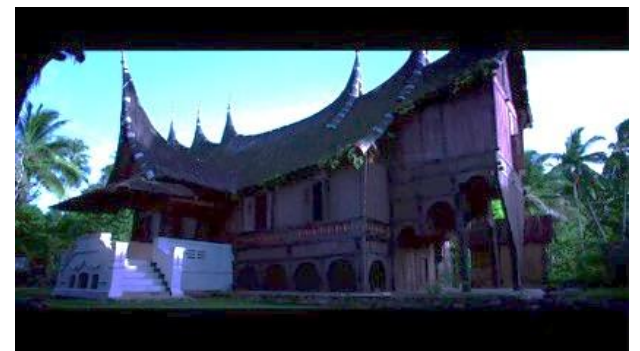

Figure 1. Rumah gadang (Tenggelamnya Kapal van der Wijck).

The variety of rumah gadang can also be conveyed through the films Harimau Tjampa, Di Bawah Lindungan Ka'bah, and Tenggelamnya Kapal van der Wijck. The rumah gadang featured in this film is the Luhak Tanah Datar house. This rumah gadang is known as the gajah maharam 'sitting elephant' because of its large volume [26] and has the characteristics of six or more gonjong [24]. In addition, the visualization of the 
rumah gadang in the film shows anjuang. Anjuang is a small room on the right and left of the rumah gadang with a higher floor. Anjuang which is located on the two sides of the rumah gadang is characteristic in Kelarasan Koto Piliang [22] and is known as the garudo tabang 'flying garuda' [27]. Nakamura [26] calls this anjuang the hips of the pointed roof of the house.

Meanwhile, the shape of Luhak Agam's rumah gadang is called surambi papek which looks like it is pressed together at both ends. Rumah gadang Luhak Limopuluah Koto is called rajo babandiang which is similar in shape to the rumah gadang in Luhak Tanah Datar but is not flat [44]. Nakamura [46] adds that there are eleven variations of the rumah gadang architectural form of the three Minangkabau luhak from its six basic forms, namely pariangan, balimbiang, balai cancang, payobasung, kudo batagak, and koto gadang.

There are various kinds of information about the basic form of this traditional house. One suggests that this basic form is taken from a boat as a figurative sailing through the oceans of life. The body is similar to the shape of a boat, while the gonjong is the crown on the boat's bow and stern. The heading's center is the boat 'bridge.' This opinion is corroborated by the nickname given to traditional housebuilders called nankodoh rajo 'ship captain king.' Another opinion suggests that the basic motive for the roof of the rumah gadang is related to the Minangkabau history. With the word kabau 'buffalo,' the gonjong rumah gadang is said to be taken from the basic form of a buffalo horn [48]. It can be said that through films, students can get to know the various rumah gadang to the transformation of the shape and function of the gonjong roofs in the Minangkabau social system.

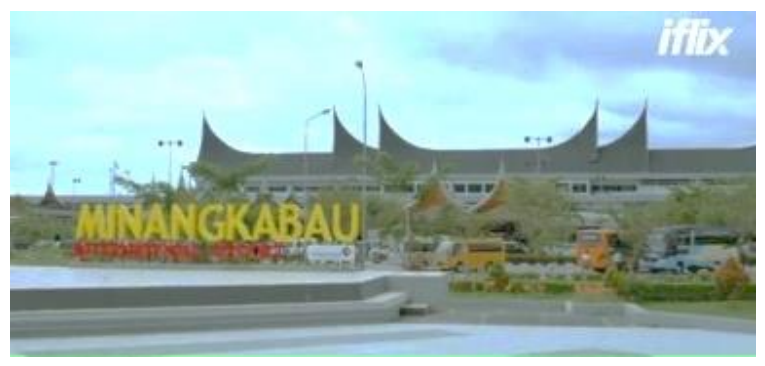

Figure 2. Gonjong roof at Minangkabau International Airport (Me vs Mami).

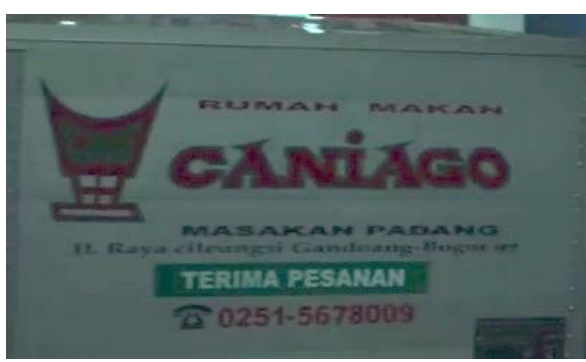

Figure 3. Rangkiang as logo (Tabula Rasa).
The films Tabula Rasa, Me vs Mami, and Liam and Laila also show changes or transformations in the use of gonjong roofs. In the three films, apart from being part of the rumah gadang, gonjong roofs appear in various ways. The gonjong roof transformation appears as the roof of office buildings, restaurant roofs, logos, and signboard ornaments. This visualization of the transformation of the gonjong roof can hone students' critical mindset, especially the reasons for the emergence of these forms of transformation.

Navis [24] stated that Minangkabau people tend to use plastic and figurative language (kieh). People commonly use expressions, pepatah, petitih, mamangan, and others in everyday conversation. This figurative usage is generally in the form of pantun and syair (rhymes and poetry). It can be said that the differences in terms that arise tend to be more figurative intent, purpose, and content. Pepatah is a figurative speech containing advice; pituah 'advice' contains teachings of ethics, wisdom, or aphorism; mamangan contains guidelines for life, rules, or prohibitions [24], [28], [29].

The use of language in this sense is found in the films Harimau Tjampa, Tenggelamnya Kapal van der Wijck, Tabula Rasa, Surau and Silek, and Liam dan Laila. However, the Minangkabau language in the context of vocabulary or terms also appears in other films.

In Tenggelamnya Kapal van der Wijck and Liam dan Laila, there is a scene of a wedding event in which the customary speech of the pasambahan 'offering'. Pasambahan is a traditional speech with a metaphorical and idiomatic style used in traditional ceremonies in Minangkabau [30]-[32]. Pasambahan is dominated by figurative language, which uses the "old-fashioned" language that the speaker has known, remembered, and even memorized. The choice of words in pasambahan shows an artistic style through playing sounds like rhymes that contain politeness and high norm values [33]. Pasambahan is a medium of communication and demonstrates language proficiency [24], [32], [34].

Figurative speech on the conversation also appears in Tenggelamnya Kapal van der Wijck and Liam dan Laila. Zainuddin is forced to stay overnight in a shop while helping Hayati lend her umbrella. At that time, the seller said that staying at his shop was not free, but he had to help wash the dishes. Dirty dishes are piled up a lot compared to the height of Mount Marapi. The allusion in Liam dan Laila appears when Ros describes the events that will occur when he hears Laila's family arguing about Laila's wedding plans. Ros described the debate's enormity and thus compared it to a household quarrel.

As a figurative form, the Minangkabau expression is a figurative language comparing with something else. By the Minangkabau people, this form of comparison is always related to the natural philosophy of alam takambang jadi guru, 'developing nature becomes a 
teacher.' All figures of speech will always be in touch with nature, people, and life.

Table 2. Pasambahan

Pasambahan
A: Sumego tumpuan puntiang syariat adat nan bapakai
nasar kapado nan basamo.
B: Ka bakeh Angku juo.
Tantangan sambah jo panitahan taratiknyo mujilih lelo
jo sopan lai bapintak jo bana Angku dijalang.
Artinyo sapanjang buah kabanaran Angku nan ka tangah
di lingkuang bari jo balabeh dikanduang adaik jo pusako
(..
(Tenggelamnya Kapal van der Wijck)

Pandang jauah alah malayang

Pandang dakek manukik mato

Nan dinanti kini lah datang

Nan dicinto lah samo tibo

Sanang rasonyo di dalam hati

Sajuak di dalam kiro-kiro

Cubadak tumbuh di laman

Ambiak ka gulai urang di dapua

Jan lah lamo tagak di jalan

Tingkek lah janjang tampiak lah bandua

Ka rumah lah Sanak

Kami mananti jo sanang ati

(Liam dan Laila)

An example of a proverb with a natural comparison is found in the Harimau Tjampa. The expressions mandi di bawah-bawah manyauak di ilia-ilia 'bathe below, choke downstream' are used when the character Saleh warns Lukman to carry himself and be modest when talking to parents and teachers. This expression illustrates the intention that in social life, one must place oneself proportionally as it should. The proverb aie di tempayan dibuang ka kali, sadang hujan antah masih dima, 'water in jar thrown to the river, while the rain still far' also uses comparison with nature. This expression intends to hope for something that is not clear, but the owned benefits are released.

The phrases lambaian gunuang Marapi, limpapeh rumah nan gadang 'wave of Mount Marapi, ornate rumah gadang' and gunuang Marapi masih tagak kokoh manjulang, adaik masih badiri kuaik, indak lapuak dek hujan, indak lakang dek paneh 'Mount Marapi is still towering, customs still stand firm, not weathered by rain, not cracked by heat ' in Tenggelamnya Kapal Van der Wijck also shows a metaphor for natural comparisons.

The use of figurative language by the Minangkabau also appears with the content of satire. The use of this satire is found in the film Tabula Rasa. When Mak and Natsir helped Hans for the first time, Hans refused harshly. With an annoyed tone, Natsir said, "Ondeh mak oi. Sabana elok bana anak mudo kini" "Oh my God. Outstanding attitude.'
Translation

A: Hopefully, the foundation of shari'a and custom is used based on the common interest.

B: Back to You too. Regarding the orderly worship and greetings of the assembly, good intentions and politeness are shown. With humility, You are welcomed. It means that as long as the truth that You propose is following heirloom customs ...

The distant view has drifted.

Look closely eye-dipping

The long-awaited has come.

The beloved has arrived.

Happy feeling in the heart

It is cool inside

Jackfruit grows on the lawn.

Taken to make curry in the kitchen

Do not stand in the street for long.

Go up the ladder, open the door.

Come inside.

We look forward to it with pleasure.

Besides that, expressions with a comparison of life also appear in this Tabula Rasa. The sentence kok iyo ka manolong inyo, agiah panciang, jan ikannyo 'if you are going to help him, give him a fishing rod, not the fish' is a phrase that was uttered by Mak when he wanted to help Hans's life by accepting him to work helping out at Mak's restaurant. Likewise, when Parmanto was asked to return to "Takana Juo" by Hans, Parmanto refused with the expression kapa tu nahkodonyo hanyo ciek, 'ship has only one captain.' Harun [35] emphasized that something that is compared does not need to be explained in terms of its nature and circumstances in the Minangkabau language. The interlocutor is considered to have known the meaning.

The brief exposition of the Minangkabau content in the films above proves that Minangkabau is worthy of being used as the subject matter for Alam Minangkabau learning. Apart from gonjong roofs, rumah gadang, rangkiang, and language, other Minangkabau content that can be found and used as teaching material is Minangkabau matrilineal kinship which includes marriage, the role, and position of mamak and kamanakan, inheritance (harato pusako); merantau (migrating); silek (silat); traditional clothing; art; traditional musical instruments; surau; lapau (tavern); and marawa (traditional flag), all of which are part of the Minangkabau universe. Determining the suitability of teaching materials with the educational grade level is also 
a crucial consideration. Content on politeness, morals, and rumah gadang, for example, is very appropriate to be given for the elementary education level. Meanwhile, the secondary and upper education levels can be given material with a broader context of social aspects, including surau, merantau, and the Minangkabau matrilineal kinship system.

\section{CONCLUSION}

The mastery of local content teaching materials, especially the Alam Minangkabau, by students should not merely be measured through values that tend to memorize the material's content. Understanding and its application in everyday life are fundamental because besides this material, it is sustainable, integrative, and locality, which is one of the characteristics of regional identity.

Selection of the right learning media will ultimately affect students' mastery and understanding of the material provided. The interest of students in learning media should be taken into account to achieve the desired learning objectives. Film as a complex form of art can be considered an alternative medium of learning which is quite useful. However, the selection must also pay attention to the content contained in the film, students' needs, and the learning objectives.

\section{REFERENCES}

[1] S. W. Littlejohn and K. A. Foss, Eds., Encyclopedia of Communication Theory. Los Angeles - London - New Delhi - Singapore Washington DC: Sage, 2009.

[2] S. Gayatri and H. N. Hidayat, "Menumbuhkembangkan Minat dan Pemahaman Siswa terhadap Kebudayaan Minangkabau dengan Media Audio Visual," $J$. War. Pengabdi. Andalas, vol. XV, no. 22, 2009.

[3] Saputranur, "Studi Tentang Representasi Tokoh Perempuan Dalam Film Titian Serambut Dibelah Tujuh Dan Ayat-Ayat Cinta 2," IAIN Samarinda, Samarinda, 2019.

[4] T. Trisnawati and C. Yesicha, "Representasi Budaya Matrilineal Minangkabau dalam Film Tenggelamnya Kapal van der Wijck," J. Ris. Komun., vol. 1, no. 2, pp. 276-284, Aug. 2018, doi: 10.24329/jurkom.v1i2.40.

[5] D. Fitri, "Representasi Ideologi Minangkabau dalam Film Surau dan Silek Ditinjau dari Kajian Semiotika," LAYAR J. Ilm. Seni Media Rekam, vol. 5, no. 2, pp. 66-77, Mar. 2018, [Online]. Available:

https://jurnal.isbi.ac.id/index.php/layar/article/vi ew/795.

[6] M. Arief, "Film Surau dan Silek (Ketika Anak-
Anak Menemukan Sebuah Makna),' ISI

Surakarta, Surakarta, Laporan Penelitian, 2018.

[7] C. A. Woodrich, "Writing about Film Adaptation : Film Adaptation in Indonesian Media Discourse," in Advances in Social Science, Education and Humanities Research, 2018, vol. 280, pp. 1-9.

[8] A. A. Thalib, "Isu-Isu Identitas Budaya Nasional dalam Film ' Tenggelamnya Kapal Van der Wijck,"' Satwika, vol. 1, no. 2, 2017, [Online]. Available:

http://ejournal.umm.ac.id/index.php/JICC.

[9] D. K. Aisya, Y. Yusril, and S. Sahrul, "Kritik Budaya Minangkabau dalam Film Di Bawah Lindungan Ka'bah," Bercadik J. Pengkaj. dan Pencipta. Seni, vol. 4, no. 2, p. 146, Oct. 2017, [Online]. Available: http://www.journal.isipadangpanjang.ac.id/index.php/Bercadik/article/ view/569.

[10] S. N. Anggraini, ““Aku Yang Galau’: Refleksi Film Masa Kolonial Hingga Awal Kemerdekaan," REKAM J. Fotogr. Telev. dan Animasi, vol. 11, no. 2, p. 79, Mar. 2016, doi: 10.24821/rekam.v11i2.1295.

[11] M. Arief, “Analisis Konteks Islam dan Budaya Minangkabau dalam Skenario Film Titian Serambut Dibelah Tujuh," Menara Ilmu, vol. X, no. 2, pp. 213-216, 2016, doi: 10.33559/MI.V10I73.66.

[12] P. Eneste, Novel dan Film. Flores: Nusa Indah, 1991.

[13] K. G. Heider, Indonesian Cinema: National Culture on Screen. Honolulu: University of Hawaii Press, 1991.

[14] U. Junus, "Di Bawah Lindungan Ka'bah: Dialog Antara Film dan Novel," Masy. Indones., vol. XI, no. 2, 1984.

[15] K. T. Hoay, "Melati van Agam: Produksi Paling Baru dari Tan's Film," Panorama, vol. 182, pp. 27-28, 1930.

[16] K. T. Hoay, "Melati van Agam: Bagian Penghabisan," Panorama, vol. 198, 1931.

[17] T. Nurseto, "Membuat Media Pembelajaran yang Menarik," J. Ekon. Pendidik., vol. 8, no. 1, pp. 19-35, 2011.

[18] T. Nurrita, "Pengembangan Media Pembelajaran untuk Meningkatkan Hasil Belajar Siswa," Misykat, vol. 03, no. 1, pp. 171-187, 2018.

[19] W. B. Russell-III, Teaching Social Issues with Film. Charlotte: IAP Information Age Publishing, Inc., 2009.

[20] J. Hadler, Sengketa Tiada Putus: Matriarkat, 
Reformisme Agama, dan Kolonialisme di

Minangkabau. Jakarta: Freedom Institute, 2008.

[21] E. Franzia, "Cultural Wisdom of Minangkabau Ethnic Community for Local - Global Virtual Identity," Mediterr. J. Soc. Sci., vol. 8, no. 1, pp. 325-329, 2017, doi: 10.5901/mjss.2017.v8n1p325.

[22] T. Kato, "Change and Continuity in the Minangkabau Matrilineal System," Indonesia, vol. 25 , no. 25 , pp. $1-16$, Apr. 1978 , doi: $10.2307 / 3350964$.

[23] L. E. Prasetya and S. M. Adi, "Makna dan Filosofi Ragam Hias Pada Rumah Tradisional Minangkabau di Nagari Pariangan Tanah Datar," in Seminar Nasional "Kearifan Lokal dalam Keberagaman untuk Pembangunan Indonesia “, 2011, pp. 59-70.

[24] A. A. Navis, Alam Terkembang Jadi Guru: Adat Dan Kebudayaan Minangkabau. Jakarta: Grafiti Press, 1984.

[25] A. Bahauddin, S. Hardono, A. Abdullah, and N. Z. Maliki, "The Minangkabau House - A Vision Of Sustainable Culture and Architecture," Int. J. Des. Nat. Ecodynamics, vol. 8, no. 4, pp. 311324, 2013, doi: 10.2495/DNE-V8-N4-311-324.

[26] S. Nakamura, "A Study of Regional Variations of Rumah Gadang Types in the Core of Minangkabau Area," J. Archit. Plan. Environ., no. 550, pp. 185-192, 2001.

[27] S. Ismael, Arsitektur Tradisional Minangkabau Nilai-nilai Budaya dalam Arsitektur Rumah Adat. Padang: Bung Hatta University Press, 2007.

[28] Syafwandi, Arsitektur Tradisional Sumatera Barat. Jakarta: Departemen Pendidikan dan Kebudayaan, 1993.

[29] Lindawati, "Mamangan Minangkabau (Sebuah Kajian Semiotik)," J. Elektron. WACANA Etn., vol. 3, no. 2, pp. 211-223, Oct. 2012, Accessed: Jul. 31, 2019. [Online]. Available:

http://wacanaetnik.fib.unand.ac.id/index.php/wa canaetnik/article/view/36.

[30] Arriyanti, "Estetika Pasambahan pada Upacara Perkawinan di Kecamatan Banuhampu, Kabupaten Agam," Madah, vol. 6, no. 2, pp. 123-136, 2015.

[31] J. Bakar, M. Esten, A. Surin, and Busri, Sastra Lisan Minangkabau: Pepatah, Pantun, dan Mantra. Jakarta: Pusat Pembinaan dan Pengembangan Bahasa Departemen Pendidikan dan Kebudayaan, 1981.

[32] Widya, "Coherence Discourse Strategies of Pasambahan: Minangkabau Cultural Discourse," Linguist. Indones., vol. 38, no. 1, pp. 35-55,
2020.

[33] H. Ardi, “'Bahasa Pasambahan' in Minangkabaunese: Politeness Strategy or Stylistic Language?," in Kongres Internasional Masyarakat Linguistik Indonesia 2014, 2014, pp. 188-191, doi: 10.31227/osf.io/26eyh.

[34] Wasana et al., "Pepatah Petitih: Its Interpretation On Instagram," 2019, doi: 10.4108/eai.29-8-2019.2289025.

[35] C. Harun, Kesenian Randai di Minangkabau. Jakarta: Proyek Pembinaan Media Kebudayaan Depdikbud, 1991. 